\title{
Changes in moisture exclusion efficiency and crystallinity of thermally modified wood with aging
}

\section{Asghar Tarmian, Akbar Mastouri}

\begin{abstract}
This study aimed to investigate whether aging affects moisture exclusion efficiency and crystallinity of thermally modified wood. For this purpose, wood blocks of hornbeam (Carpinus betulus), Norway spruce (Picea abies) and oak (Quercus castanifolia), modified at $180{ }^{\circ} \mathrm{C}$ for 3 hours inside a ThermoWood kiln were exposed to a six-cycle artificial aging procedure. Aging reduced the efficiency and crystallinity of the modified woods. A significant negative correlation was found between the wood crystallinity and equilibrium moisture content (EMC) which indicates that change in the crystallinity index $(\mathrm{Crl})$ measured by X-ray diffraction (XRD) affects the affinity of wood to moisture. The increased affinity of the modified wood to moisture after aging is probably due to the leaching of thermal degradation products as observed by Attenuated Total Reflectance Fourier Transform Infrared (ATR-FTIR) spectroscopy.
\end{abstract}

Keywords: Aging, Crystallinity, Moisture Exclusion Efficiency, Thermally Modified Wood

\section{Introduction}

The hygroscopicity of wood is responsible for many challenges of using wood for outdoor applications where exposure to high humidity and rain is concerned. Thermal modification is the most widely used commercial process to reduce the affinity of wood to moisture uptake. Reduction in the accessible hydroxyl groups of wood due to thermal degradation of hemicelluloses, increase in the cellulose crystallinity, and crosslinking in lignin were suggested to be the main reasons for reducing the hygroscopicity of wood due to the thermal modification (Esteves \& Pereira 2009). It is supposed that irreversible changes in the physical and mechanical properties of a material occur during aging (Unger et al. 2001). Contradictory results were reported for the effect of natural aging on the equilibrium moisture content (EMC) of wood (Kranitz et al. 2016). However, most literatures found that the EMC of wood decreases with an increase in wood age (Kranitz et al. 2016).

Crystallinity refers to the amount of crystalline region in the material with respect

to the amorphous content. Among wood components, cellulose is semi-crystalline, but hemicelluloses and lignin are amorphous. The crystallinity of wood is often estimated by analytical techniques, such as X-ray diffraction (XRD), FT-IR, carbon-13 NMR and near-infrared (NIR) spectroscopy (Newman \& Hemmingson 1990, Esteban et al. 2006, Jiang et al. 2007, Poletto et al. 2012, Lionetto et al. 2012). The degree of crystallinity has a noticeable influence on different properties of wood, including thermal stability, mechanical strength, hardness, density and hygroscopicity (Esteban et al. 2006, Lionetto et al. 2012, Poletto et al. 2012). A comprehensive literature review conducted by Kranitz et al. (2016) showed that the natural aging may have different effects on the crystallinity of wood. A number of authors reported an increase in the degree of crystallinity of wood as a result of heat treatment (Kubojima et al. 1998, Bhuiyan et al. 2000, Wang et al. 2015). An increase in the crystallinity during the early stages of thermal modification, when the mass loss is low, is due to the molecular reorientation rather than the

$\square$ University of Tehran, Faculty of Natural Resources, Department of Wood and Paper Science and Technology, Tehran (Iran)

@ Asghar Tarmian (tarmian@ut.ac.ir)

Received: Jan 06, 2018 - Accepted: Nov 10, 2018

Citation: Tarmian A, Mastouri A (2019). Changes in moisture exclusion efficiency and crystallinity of thermally modified wood with aging. iForest 12: 92-97. - doi: 10.3832/ifor2723-011 [online 2019-01-24]

Communicated by: Giacomo Goli loss of amorphous components (hemicelluloses) of wood (Hill 2006).

Until now, few studies have reported the effect of weathering on the moisture exclusion efficiency of thermally modified wood (Nuopponen et al. 2004, Huang et al. 2012, Cermák et al. 2015) and there is no study exploring changes in the crystallinity of thermally modified wood after aging. It is claimed that thermally modified wood is more resistant to weathering than untreated wood due to largely unleachable weathering products of lignin (Nuopponen et al. 2004, Huang et al. 2012). However, an increase in the wettability of the modified wood after re-wetting cycles was reported as a result of artificial weathering and reduction in its anti-swelling efficiency (Huang et al. 2012, Cermák et al. 2015).

In contrast to artificial weathering, other parameters affecting the service life of a product, such as winter temperatures, thermal degradation and maximum shrinkage, can be simulated by applying artificial aging. Reduction in the moisture exclusion efficiency of thermally modified wood after cycled moisture sorption and water soaking is often explained by the recovery of annealing effects of wood amorphous polymers (Biziks et al. 2015, Endo et al. 2016, Altgen \& Militz 2016, Wentzel et al. 2018). In addition to the annealing effects, the cell wall bulking effect caused by thermal degradation products is responsible for a non-permanent reduction in the moisture sorption of thermally modified wood. The accumulated degradation products can be removed by water soaking, resulting in an increase of EMC. However, none of the above mentioned studies has directly examined the changes in crystallinity of thermally modified wood after artificial 


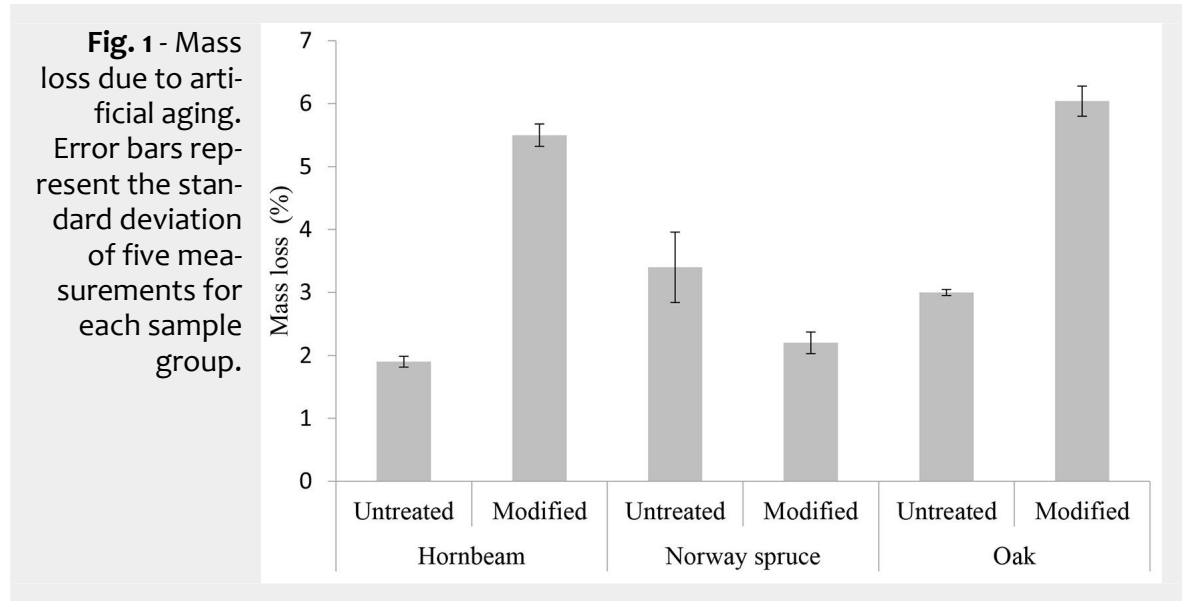

aging. Thus, the main purpose of this study is to determine how the crystallinity index (Crl) of thermally modified wood changes due to artificial aging, and to find out if the crystallinity of modified wood contributes to the changes in the moisture exclusion efficiency. Furthermore, our aging process gives more information about the efficacy of thermally modified wood that is affected by freezing or high temperature in addition to wetting-drying cycles.

\section{Materials and methods}

\section{Wood sampling and thermal} modification oak heartwood (Quercus castanifolia) and Norway spruce (Picea abies) with $20 \mathrm{~mm}$ in thickness were thermally modified inside a ThermoWood kiln. First, the boards were dried by a fast high-temperature drying process. During the drying phase, the kiln temperature was first raised rapidly to about $100^{\circ} \mathrm{C}$ and then increased steadily to $140{ }^{\circ} \mathrm{C}$ to reduce the moisture content of wood to almost zero. After drying, thermal modification was carried out at the target temperature of $180{ }^{\circ} \mathrm{C}$ for 3 hours. Finally, cooling and conditioning were applied for $24 \mathrm{~h}$ to bring the moisture content to about $7 \%$.

\section{Artificial aging procedure} mens were exposed to a six-cycle artificial aging according to $V_{3} 13$ procedure, European Standard EN 321. The specimens were exposed to immersion in distillated water
Boards of hornbeam (Carpinus betulus),

Control and thermally modified speci-

at $20{ }^{\circ} \mathrm{C}$ for $72 \mathrm{~h}$, freezing at $-12{ }^{\circ} \mathrm{C}$ for $24 \mathrm{~h}$, drying at $70^{\circ} \mathrm{C}$ for $72 \mathrm{~h}$, and settled at room temperature for $4 \mathrm{~h}$.

Measuring moisture exclusion efficiency Equilibrium moisture content (EMC) of specimens was measured in a climatic chamber at $20{ }^{\circ} \mathrm{C}$ and $65 \% \mathrm{RH}$. The EMC of aged samples was determined as follows (eqn. 1):

$$
\operatorname{EMC}(\%)=\frac{m_{2}-m_{1}}{m_{1}} \cdot 100
$$

where $m_{1}$ is the oven dried mass of samples after aging and $m_{2}$ is the mass after equilibration in the climatic chamber for three weeks. Unaged samples were also used as references for determining the EMC before aging. The moisture exclusion efficiency (MEE) of specimens was then calculated as (eqn. 2):

$$
\operatorname{MEE}(\%)=\frac{E_{u}-E_{m}}{E_{u}} \cdot 100
$$

where $E_{u}$ and $E_{m}$ are the EMC values of untreated and modified wood, respectively. Five repetitions were used for each treatment.

\section{ATR-FTIR studies}

Attenuated total reflectance Fourier transform infrared (ATR-FTIR) spectroscopy was used to investigate the chemical changes of wood specimens due to aging. Spectra were recorded on Bruker Tensor $27^{\oplus}$ ATR-FTIR device equipped with the software OPUS ver. 7.2 (Bruker Optik $\mathrm{GmbH}$, Fällanden, Switzerland). Spectra were baseline corrected by the concave

Tab. 1 - Mean EMC values ( \pm standard deviation) of wood samples before and after aging.

\begin{tabular}{llrr}
\hline Species & Status & \multicolumn{2}{c}{ EMC (\%) } \\
\cline { 3 - 4 } & & \multicolumn{1}{c}{ Control } & \multicolumn{1}{c}{ Aged } \\
\hline Oak & Unmodified & $9.5 \pm 0.02$ & $10.7 \pm 0.30$ \\
\cline { 2 - 3 } Norway spruce & Modified & $5.8 \pm 0.17$ & $7.6 \pm 0.41$ \\
& Unmodified & $8.2 \pm 0.47$ & $10.0 \pm 0.30$ \\
\cline { 2 - 4 } Hornbeam & Modified & $4.7 \pm 0.16$ & $8.4 \pm 0.15$ \\
& Unmodified & $9.6 \pm 0.10$ & $10.5 \pm 0.24$ \\
\cline { 2 - 4 } & Modified & $5.2 \pm 0.47$ & $7.7 \pm 0.27$ \\
\hline
\end{tabular}

rubber band method (ten iterations, 64 baseline points) and min-max normalized. The FT-IR spectrum was recorded for each sample in the wavenumber range of 4000$400 \mathrm{~cm}^{-1}$ with 64 scans per analysis at spectral resolution of $4 \mathrm{~cm}^{-1}$.

\section{$X$-ray diffraction (XRD)}

X-ray diffraction (XRD) analysis was carried out on wood powder samples with Co Ka radiation $(\lambda=1.78 \AA, 40 \mathrm{kV}, 30 \mathrm{~mA})$ to quantify the degree of wood crystallinity. Intensities were measured in the range of $5^{\circ}<2 \theta<50^{\circ}$ with scan steps of $0.04^{\circ}$. The crystallinity index $(\mathrm{Crl})$ was calculated base on the following ratio (Segal et al. 1959 eqn. 3):

$$
\operatorname{CrI}(\%)=\frac{I_{200}-I_{a m}}{I_{200}} \cdot 100
$$

where $I_{200}$ is the intensity of the crystalline peak at $2 \theta=22.6^{\circ}$, reflecting both crystal and amorphous material, and $l_{\mathrm{am}}$ is the minimum intensity between the 200 and 101 peaks at $2 \theta=18.5^{\circ}$, reflecting only amorphous material. Two measurements were performed for each sample group.

\section{Results and discussions}

\section{Mass loss}

The mass loss ranged from 1.9 to $6 \%$ after exposure to six cycles of aging, with the highest value for modified oak (Fig. 1). Except Norway spruce, the mass loss was greater for thermally modified wood compared to the control wood. The mass loss is mainly due to the reduction in the watersoluble extractives of wood specimens during wetting cycles of aging. Thermal modification causes an increase in the extractives content (Cermák et al. 2015) which are leach out during aging. Our aging results showed that the greatest leachable materials were formed in oak due to the modification.

\section{Moisture exclusion efficiency}

In agreement with a number of previous studies (Esteves \& Pereira 2009), all thermally modified woods had an evident lower EMC than the untreated woods, and the best moisture exclusion efficiency (49.3\%) was observed in hornbeam. Reduction in EMC due to heat treatment ranges from $0 \%$ to $50 \%$, depending on the treatment conditions (Chirkova et al. 2005). A higher heat-treating temperature causes a greater EMC reduction. Moisture exclusion efficiency (MEE) of the modified wood is mainly due to irreversible chemical changes of the cell wall components and degradation of hemicelluloses. However, the MEE of thermally modified wood specimens seems to be overestimated due to reversible annealing effects caused by drying at elevated temperature $\left(100-140{ }^{\circ} \mathrm{C}\right)$ beyond the softening point of amorphous polymers during the thermal modification process. It is claimed that the reduction in 
hygroscopicity of thermally modified wood is due to both reversible and irreversible effects, and the annealing of amorphous wood polymers is responsible for the former effect (Endo et al. 2016). The reversible change in the hygroscopicity may also be due to the presence of degradation products of thermal modification, which reduce the wood porosity by occupying the nanopores of the cell walls (Wentzel et al. 2018). In contrast to the common belief that the hydroxyl groups available for moisture uptake are significantly reduced by the heat treatment, Rautkari et al. (2013) found a poor correlation between EMC and the accessibility of hydroxyl groups, indicating that there are other mechanisms controlling the EMC in addition to the hydroxyl group accessibility.

Tab. 1 shows the EMC of wood samples before and after aging. The moisture exclusion efficiency of thermally modified wood due to aging decreased by $8.8 \%$ in oak, $61.1 \%$ in Norway spruce and $46.1 \%$ in hornbeam (Fig. 2). Literature reviews show contradictory trends concerning the hygroscopic behavior of naturally aged wood, but in most cases EMC slightly decreases with increasing age (Kranitz et al. 2016). The main reason for the reduction in moisture exclusion efficiency is the leaching of extractives and accumulated thermal degradation products during aging, as observed by ATR-FTIR. Both cell wall bulking and annealing effects on the hygroscopicity of thermally modified wood fully disappeared during water soaking (Biziks et al. 2015, Altgen et al. 2016, Wentzel et al. 2018). However, the drying-related annealing effects can also be partially removed by exposure to the elevated relative humidity. Most of extractives, such as resin acids, disappears from wood after heat treatment (Nuopponen et al. 2003), but new complex polyaromatic compounds are formed due to the degradation of cell wall components (Esteves \& Pereira 2009), which can be water soluble. A summary of IR bands observed in the wood samples is given in Tab. 2. An absorption band was observed in the carbonyl group region of wood samples at $1740 \mathrm{~cm}^{-1}$ (Fig. 3), showing a reduction in the peak intensity due to thermal modification, caused by degradation of hemicelluloses. The reduction might also be caused by the leaching of remaining acetic acid in thermally modified wood. As observed for oak, the reduced intensity due to aging confirms the removal of fats and waxes by the aging procedure. The intensity of peak at $1516 \mathrm{~cm}^{-1}$ also was slightly reduced which suggests the removal of aromatic extractives, such as dehydroabietic acid, lignans, and stilbenes (Nuopponen et al. 2003) due to aging. The peak at $1277 \mathrm{~cm}^{-1}$ originated from the $\mathrm{C}-\mathrm{O}$ stretching vibrations of softwood resin acids (Nuopponen et al. 2003) was observed in Norway spruce even after aging. Removal of extractives was reported to cause an increase in EMC, fiber saturation point (FSP) and dimensional

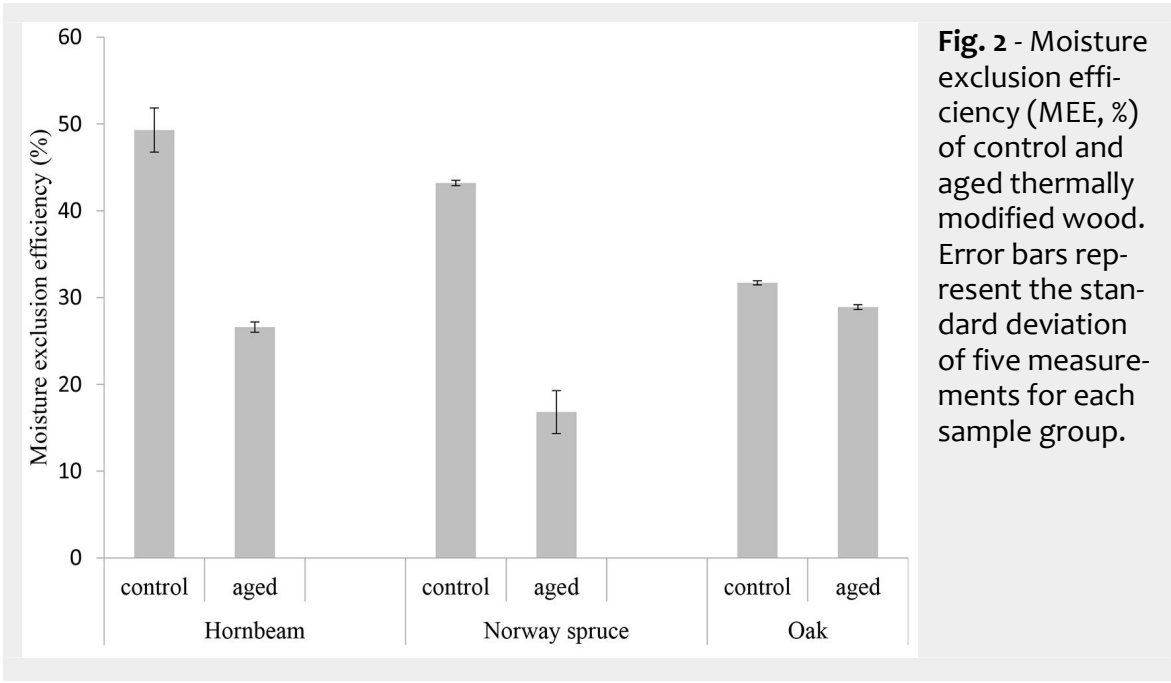

Tab. 2 - Assignment of major absorption IR spectra peaks in wood samples.

\begin{tabular}{cl}
\hline $\begin{array}{c}\text { Wavenum- } \\
\text { ber }\left(\mathrm{cm}^{-1}\right)\end{array}$ & Band assignment \\
\hline 1740 & unconjugated C=O stretching \\
1590 & $\mathrm{C}=\mathrm{C}$ stretching of the aromatic ring in lignin \\
1516 & Aromatic skeletal vibration \\
1460 & $\mathrm{C}=\mathrm{H}$ deformation (methyl and methylene) \\
1425 & asymmetric $\mathrm{CH}$ 2 deformation in cellulose \\
1367 & CH deformation in cellulose and hemicellulose \\
1277 & C-O stretching vibrations of softwood resin acids \\
1155 & C-O-C vibration in cellulose and hemicellulose \\
1105 & Aromatic skeletal and C-O stretching vibration of polysaccharides and lignin \\
1024 & C-O stretching in cellulose and hemicellulose \\
892 & C-H deformation in cellulose \\
\hline
\end{tabular}

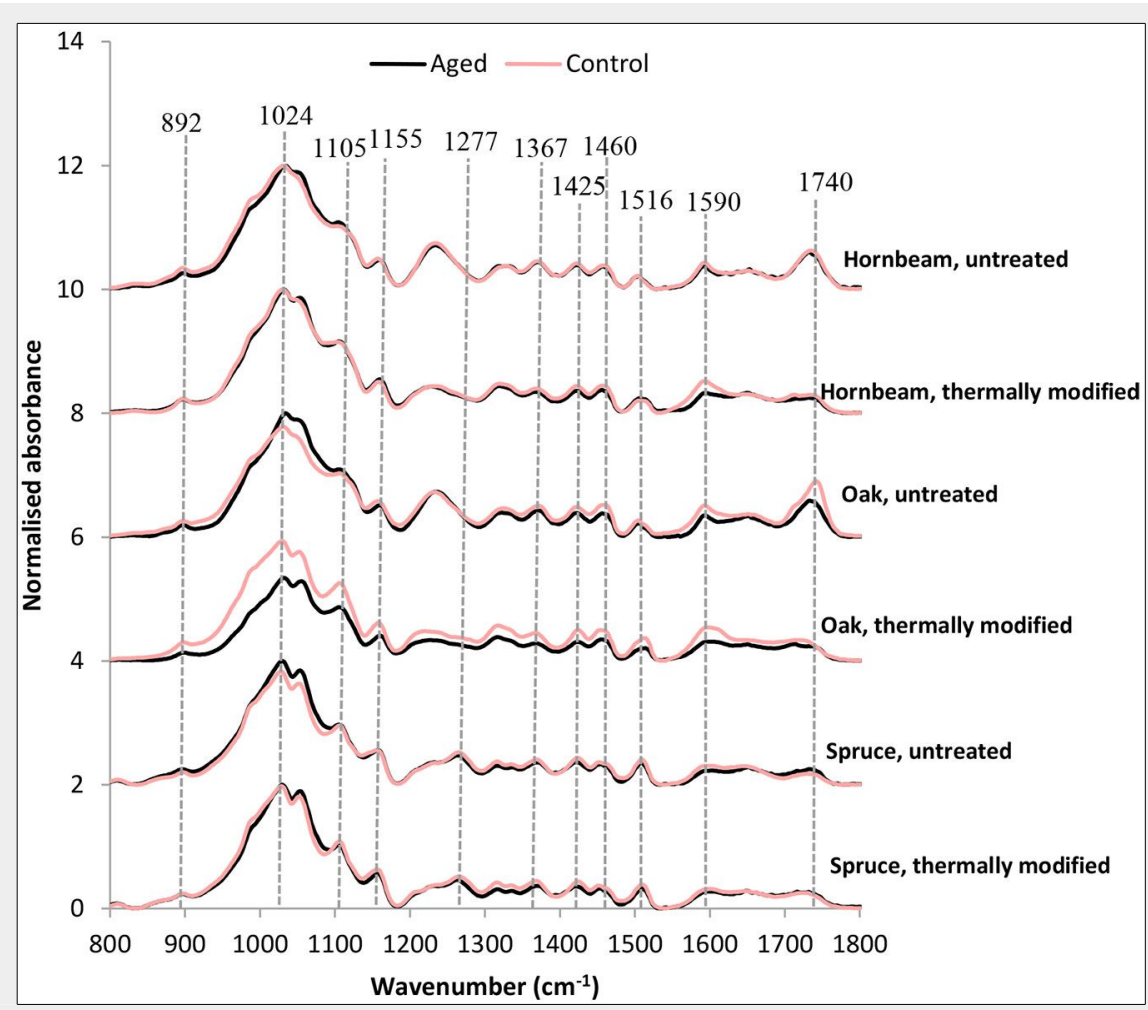

Fig. 3 - Average ATR-FTIR spectra in the range of $800-1800 \mathrm{~cm}^{-1}$ for control and thermally modified woods before (red line) and after (black line) aging. 

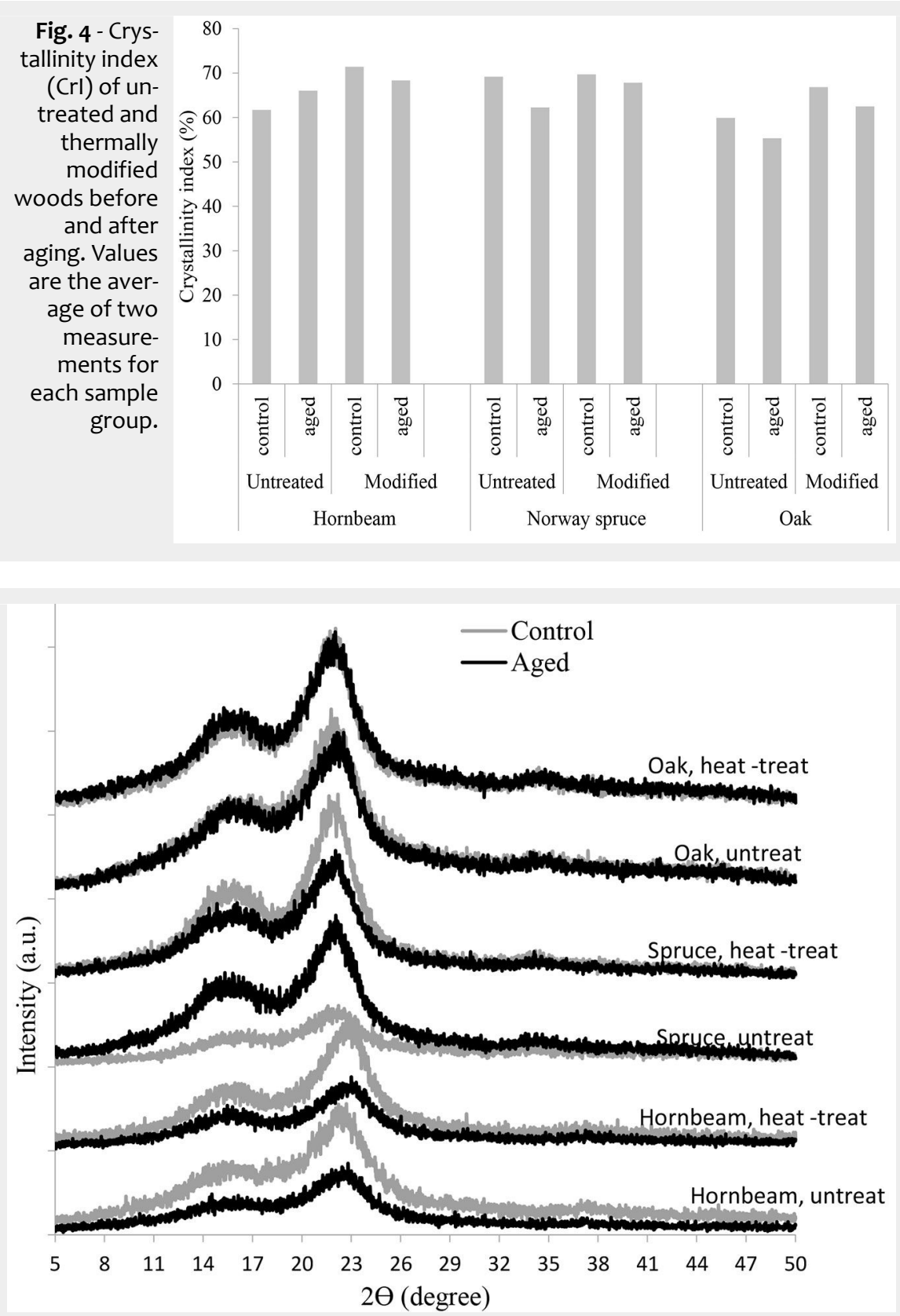

Fig. 5 - XRD curves of untreated and thermally modified woods before (gray lines) and after (black lines) aging.

Fig. 6 - Correlation between the wood crystallinity and EMC for control and aged samples.

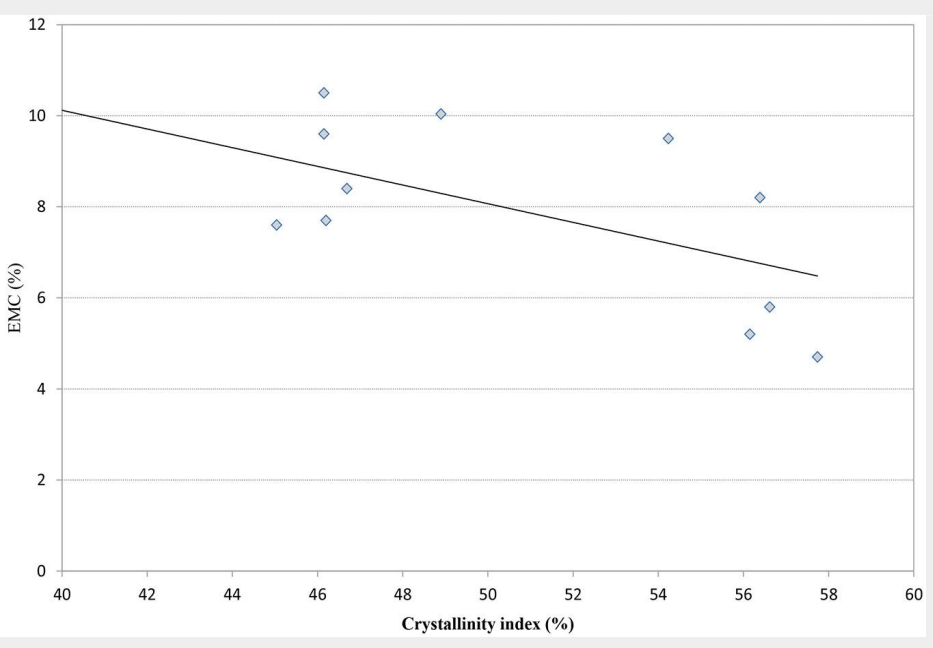

changes of wood (Hernández 2007). It is believed that nanopores in the cell wall matrix may be occupied by accumulated degradation products, thereby causing reduction in the hygroscopicity of wood after thermal modification (Wentzel et al. 2018). Other chemical changes may contribute to the hygroscopicity of aged thermally modified wood, in addition to possible effect of leaching of extractives and thermal degradation products.

\section{Crystallinity}

The crystallinity index $(\mathrm{Crl})$ of the wood specimens was increased after thermal modification (Fig. 4), which is in agreement with previous studies (Bhuiyan et al. 2000, Akgul et al. 2007, Huang et al. 2012). The decomposition of amorphous regions in cellulose and hemicelluloses, as well as the crystallization of amorphous cellulose due to thermal degradation, causes an increase in crystallinity of the modified wood (Esteves \& Pereira 2009, Inagaki et al. 2010). However, it is worth noting that the loss of hemicelluloses due to thermal effects, as confirmed by reduction in the intensity of FTIR peak at $1740 \mathrm{~cm}^{-1}$ (Fig. 3), also leads to the enrichment of the relative crystalline content.

Aging reduced the crystallinity of the modified woods by around $17.1 \%$ in hornbeam, $19.1 \%$ in Norway spruce and $20.4 \%$ in oak (Fig. 4), probably due to the removal of extractives and the effects of repeated wetting and drying cycles of aging. It has been hypothesized that noncrystalline cellulose forms hydrogen bonds with cellulose at the surface of crystalline region due to the repeated moisture changes (Toba et al. 2013). Drying at high temperatures also results in the cellulose crystallization in the noncrystalline region (Rayirath et al. 2008, Sik et al. 2010). Drying does not alter cellulose crystallinity or cellulose crystalline structure, though it affects the size of microfibril bundles and thus the cellulose accessibility to water (Sik et al. 2010). Random (cold) crystallization in the quasi-crystalline region of wood cellulose may also increase the crystallinity of wood. No changes occurred in the diffraction pattern of wood specimens after aging and the peaks were not shifted (Fig. 5). The crystalline structure of wood cellulose microfibers hinders the access of water molecules to the $\mathrm{OH}$ groups. Reduction in the degree of cellulose crystallinity in naturally aged wood of Pinus sylvestris L. was reported to have a major influence on the wood hygroscopicity (Esteban et al. 2006).

Crystallinity index of wood may vary depending on the measurement method. $X$ ray diffraction is often used for measuring the crystallinity of wood materials (Park et al. 2010, Lionetto et al. 2012, Agarwal et al. 2017). The crystallinity can be also estimated by using different absorbance ratios in IR spectra, for example 1375 to $1521 \mathrm{~cm}^{-1}$, 1427 to $896 \mathrm{~cm}^{-1}, 1372$ to $2885 \mathrm{~cm}^{-1}, 1373$ to $1350 \mathrm{~cm}^{-1}, 1373$ to $667 \mathrm{~cm}^{-1}$ and 1317 to 1336 
$\mathrm{cm}^{-1}$ (Colom et al. 2003, Kasprzyk \& Wichlacz 2004, Fackler et al. 2011). The peak at $1375 \mathrm{~cm}^{-1}$ is caused by symmetric $\mathrm{CH}$ deformation in cellulose and the peak at 1512 $\mathrm{cm}^{-1}$ is characteristic of lignin (Lionetto et al. 2012). The peaks at $1317 \mathrm{~cm}^{-1}$ and 1336 $\mathrm{cm}^{-1}$ are related to crystallised and amorphous cellulose, respectively (Colom et al. 2003). Although the crystallinity index determined by FTIR spectroscopy may have a good correlation with that measured by $\mathrm{X}$ ray diffraction technique (Kasprzyk \& Wichlacz 2004), the latter gives more accurate result. However, it is accepted that XRD technique cannot provide reliable absolute values of crystallinity but only relative values (Park et al. 2010). Pearson's correlation test showed that there is a significant negative correlation between the crystallinity and EMC of wood samples $(r=-0.69, p<$ 0.05 - Fig. 6).

\section{Conclusions}

We found that the moisture exclusion efficiency and crystallinity of thermally modified wood were reduced due to aging. The increased hygroscopic nature of thermally modified wood after aging confirms the role of reversible effects caused by thermal degradation products in controlling the hygroscopicity. A significant negative correlation, observed between the crystallinity and EMC also indicates that change in the crystallinity index $(\mathrm{Crl})$ of thermally modified wood after aging is one of the several factors which may affect the EMC.

\section{Acknowledgements}

Some parts of this study were carried out in Wood Materials Science Group at the Institute for Building Materials at ETH Zurich. The authors are grateful to Prof. Ingo Burgert and Prof. Emil Engelund Thybring.

\section{References}

Agarwal UP, Ralph SA, Baez C, Reiner RS, Verrill SP (2017). Effect of sample moisture content on XRD-estimated cellulose crystallinity index and crystallite size. Cellulose 24: 1971-1984. doi: 10.1007/s10570-017-1259-0

Akgul M, Gumuskaya E, Korkut S (2007). Crystalline structure of heat-treated Scots pine [Pinus sylvestris L.] and Uludag fir [Abies nordmanniana (Stev.) subsp. Bornmuelleriana (Mattf.)] wood. Wood Science and Technology 41: 281289. - doi: 10.1007/s00226-006-0110-9

Altgen M, Hofmann T, Militz H (2016). Wood moisture content during the thermal modification process affects the improvement in hygroscopicity of Scots pine sapwood. Wood Science and Technology 50: 1181-1195. - doi: 10.1007/soo2 26-016-0845-x

Altgen M, Militz H (2016). Influence of process conditions on hygroscopicity and mechanical properties of European beech thermally modified in a high-pressure reactor system. Holzforschung 70 (10): 971-979. - doi: 10.1515/hf2015-0235

Biziks V, Andersons B, Sansonetti E, Andersone I, Militz H, Grinins J (2015). One-stage thermohydro treatment (THT) of hardwoods: an analysis of form stability after five soaking-drying cycles. Holzforschung 69: 563-571. - doi: 10.1515/ hf-2014-0083

Bhuiyan MTR, Hirai N, Sobue N (2000). Changes of crystallinity in wood cellulose by heat treatment under dried and moist conditions. Journal of Wood Science 46 (6): 431-436. - doi: 10.1007/ BFo0765800

Cermák P, Rautkari L, Horáček P, Saake B, Rademacher P, Sablík P (2015). Analysis of dimensional stability of thermally modified wood affected by re-wetting cycles. BioResources 10 (2): 3242-3253. - doi: 10.15376/biores.10.2.32423253

Chirkova J, Andersons B, Andersone I, Militz H (2005). Water sorption properties of thermomodified wood. In: Proceedings of the " 2 nd European Conference on Wood Modification". Göttingen (Germany) 6-7 Oct 2005. European Cooperation in Science and Technology, COST Action FP 1303, pp. 65-69. [online] URL: http:// costfp1303.iam.upr.si/en/

Colom X, Carrillo F, Nogués F, Garriga P (2003). Structural analysis of photodegradated wood by means of FT-IR spectroscopy. Polymer Degradation and Stability 80: 543-549. - doi: 10.1016/S0141-3910(03)00051-X

Endo K, Obataya E, Zeniya N, Matsuo M (2016). Effects of heating humidity on the physical properties of hydrothermally treated spruce wood. Wood Science and Technology 50 (6): 1161-1179. - doi: 10.1007/s00226-016-0822-4

Esteban LG, Fernandez FG, Garcia F, Casasus AG, Palacios PP, Gril J (2006). Comparison of the hygroscopic behavior of 205-year-old and recently cut juvenile wood from Pinus sylvestris $L$. Annals of Forest Science 63: 309-317. - doi: 10.1051/forest:2006010

Esteves BM, Pereira HM (2009). Wood modification by heat treatment: a review. Bioresources 4 (1): 370-404.

Fackler K, Stevanic JS, Ters T, Hinterstoisser B, Schwanninger M, Salmén L (2011). FT-IR imaging microscopy to localise and characterise simultaneous and selective white-rot decay within spruce wood cells. Holzforschung 65: 411420. - doi: 10.1515/hf.2011.048

Hernández RE (2007). Effects of extraneous substances, wood density and interlocked grain on fiber saturation point of hardwoods. Wood Material Science and Engineering 2 (1): 45-53. - doi: 10.1080/17480270701538425

Hill CAS (2006). Wood modification: chemical, thermal and other processes. John Wiley and Sons, Chichester, UK, pp. 260.

Huang $X$, Kocaefe D, Kocaefe Y, Boluk Y, Pichette A (2012). Study of the degradation behavior of heat-treated jack pine (Pinus banksiana) under artificial sunlight irradiation. Polymer Degradation and Stability 97 (7): 1197-1214. - doi: 10.1016/j.polymdegradstab.2012.03.022 Inagaki T, Siesler HW, Mitsui K, Tsuchikawa S (2010). Difference of the crystal structure of cellulose in wood after hydrothermal and aging degradation: a NIR spectroscopy and XRD study. Biomacromolecules 11 (9): 2300-2305. doi: 10.1021/bm100403y

Jiang ZH, Yang Z, So SH, Hse CY (2007). Rapid prediction of wood crystallinity in Pinus elliotii plantation wood by near-infrared spectroscopy. Journal of Wood Science 53 (5): 449-453. doi: 10.1007/s10086-007-0883-y

Kasprzyk H, Wichlacz K (2004). Some aspects of estimation of the crystallinity of gamma radiation wood cellulose by FTIR spectroscopy and X-ray diffraction techniques. Acta Scientiarum Polonorum Silvarum 3 (1): 73-84 [online] URL: http://www.forestry.actapol.net/pub/7_1_2004. pdf

Kranitz K, Sonderegger W, Bues CT, Niemz P (2016). Effects of aging on wood: a literature review. Wood Science and Technology 50: 7-22. - doi: 10.1007/s00226-015-0766-0

Kubojima Y, Okano T, Ohta M (1998). Vibrational properties of sitka spruce heat-treated in nitrogen gas. Journal of Wood Science 44: 73-77. doi: $10.1007 /$ BFo0 521878

Lionetto F, Sole RD, Cannoletta D, Vasapollo G, Maffezzoli A (2012). Monitoring wood degradation during weathering by cellulose crystallinity. Materials 5: 1910-1922. - doi: 10.3390/ma5101 910

Newman RH, Hemmingson JA (1990). Determination of the degree of crystallinity of cellulose in wood by carbon-13 NMR spectroscopy. Holzforschung 44: 351-355. - doi: 10.1515/hfsg.1990. 44.5.351

Nuopponen N, Vuorinen T, Jamsa S, Viitaniemi $\mathrm{P}$ (2003). The effects of a heat treatment on the behavior of extractives in softwood studied by FTIR spectroscopic methods. Wood Science and Technology 37: 109-115. - doi: 10.1007/s002 26-003-0178-4

Nuopponen N, Wikberg $\mathrm{H}$, Vuorinen T, Maunu SL, Jamsa S, Viitaniemi P (2004). Heat-treated softwood exposed to weathering. Journal of Applied Polymer Science 91: 2128-2134. - doi: 10.1002/app.13351

Park S, Baker JO, Himmel ME, Parilla PA, Johnson DK (2010). Cellulose crystallinity index: measurement techniques and their impact on interpreting cellulose performance. Biotechnology for Biofuels 3: 1-10. - doi: 10.1186/1754-68343-10

Poletto M, Zattera AJ, Forte MM, Santana RM (2012). Thermal decomposition of wood: Influence of wood components and cellulose crystallite size. Bioresource Technology 109: 148153. - doi: 10.1016/j.biortech.2011.11.122

Rautkari L, Hill CAS, Curling S, Jalaludin Z, Ormondroyd $G$ (2013). What is the role of the accessibility of wood hydroxyl groups in controlling moisture content? Journal of Material Science 48: 6352-6356. - doi: 10.1007/s10853-0137434-2

Rayirath P, Avramidis S, Mansfield SD (2008). The effect of wood drying on crystallinity and microfibril angle in Black Spruce (Picea mariana). Journal of Wood Chemistry and Technology 28 (3): 167-179. - doi: 10.1080/02773810802 346950

Segal L, Creely JJ, Martin Jr AE, Conrad CM (1959). An empirical method for estimating the degree of crystallinity of native cellulose using the x-ray diffractometer. Textile Research Journal 29: 786-794. - doi: 10.1177/004051755902901 003

Sik HS, Choo KT, Zakaria S, Ahmad S, Yusoff M, Chia $\mathrm{CH}$ (2010). The influence of drying temperature on the hygroscopicity of rubberwood (Hevea brasiliensis). Journal of Agricultural Science 2 (1): 48-58. - doi: 10.5539/jas.v2n1p48 
Toba K, Yamamoto H, Yoshida M (2013). Crystallization of cellulose microfibrils in wood cell wall by repeated dry-and-wet treatment, using $X$-ray diffraction technique. Cellulose 20: 633643. - doi: 10.1007/s10570-012-9853-7

Unger A, Schniewind AP, Unger W (2001). Conservation of wood artifacts. Springer, Berlin, Germany, pp. 578. [online] URL: http://books.
google.com/books?id=M5vClojlCCUC

Wang X, Wu Z, Fang L, Wei P, Fei B, Liu J (2015). Changes of chemical composition, crystallinity, and Fourier transform infrared spectra of Eucalypt pellita wood under different vacuum heat treatment temperatures. Forest Products Journal 65 (7-8): 346-351. - doi: 10.13073/FPJ-D-1300099
Wentzel M, Altgen M, Militz H (2018). Analyzing reversible changes in hygroscopicity of thermally modifed eucalypt wood from open and closed reactor systems. Wood Science and Technology 52: 889. - doi: 10.1007/s00226-0181012-3 